\title{
Effect of capital structure on the performance of firms: Evidence from Pakistan and Indian stock market
}

\author{
Abbas Ali* \\ Business Administration, University of Gujrat, Gujrat, Pakistan
}

\begin{abstract}
This purpose of this study is to find the influence of various firm level characteristics such as, leverage, participation of equity and insider ownership on the profitability of the Pakistani and Indian listed corporations in the two major stock exchanges Karachi and Bombay stock exchanges in each country respectively and then comparison of the finding between two countries. Employing the cross-sectional data methodology, $i$ examine the leverage, participation of equity, profitability and insider ownership of 84 companies in Pakistan and 75 companies in India from KSE 100 index and BSE 100 index respectively for the time period of 2000 - 2010 inclusive both year. Different conditional theories of capital structure are reviewed (the trade-off theory, pecking order theory, agency theory, and theory of free cash flow) in order to formulate testable propositions concerning the determinants of firms performance. Four variables multiple regression models are used to estimate the effect of firm level attributes on profitability. The results obtained from three different regression models show that profitability and long term leverage are negatively correlated in both KSE and BSE corporations. Moreover I find that insider ownership is positively related to profitability and it is significant in the KSE and it is insignificant in BSE listed corporations. Furthermore participation of equity is positively related in to profitability of both KSE and BSE listed corporations which are showing significant impact with Karachi stock exchange listed companies that are significance at the $1 \%$ significance level and in Bombay stock exchange it is insignificant. This study suggests that companies should implement effective and efficient capital structure policy which improves the performance and profitability. Practical implications This study has laid some groundwork to explore the determinants of firm's performance of Pakistani and Indian firms upon which a more detailed evaluation could be based. Furthermore, empirical findings should help corporate managers to make optimal capital structure decisions that will enhance the firm value and shareholders wealth.
\end{abstract}

Key words: Leverage, Agency theory, EBIT

\section{Background:}

Asia Pacific is an area including different regional boundaries Southeast Asia, East Asia, South Asia and Australasia. Due to its size and geographical position, as well as it diverse governments, history and culture and labour market Asia Pacific holds an ample of opportunities for investors. From outsourcing production to take advantage of lower costs, to reaching out to new target customers Asia pacific is always attraction for the companies across the globe. Karachi and Bombay stock exchange are among Asia's rising stock markets. There are several reasons for bullish streak in the Asia pacific, including recent political stability. The Karachi Stock Exchange and Bombay stock exchanges are also shines on strong fundamentals and technical reasons, analysts say. Looking at a turbulent 2007 and worldwide credit crisis, a quick examination of the first three months of 2008 Pakistan's benchmark KSE-100 Index and India's BSE-100 index appears as a car without breaks Already the KSE-100 has closed at records highs several times this year, the latest at a record 15,472 on $4^{\text {th }}$ April 2008. Due to all these factors my interest in studying Asian markets increases and this study trying to investigate two important countries in Asia pacific, Pakistan and India both are considered as emerging markets there is lot of potential in the both of the markets and India is mostly attraction for the foreign direct investment after china in the region due to high returns. So this research trying to investigate the effect of leverage, insider ownership and participation of equity on the performance of firms. There are lot of research on the determinants of capital structure in Pakistani and Indian market but this research is trying to shed light on the capital structure policy issues in a different and interesting way.

Besides the fundamental theory of Modigliani and Miller on the capital structure, the alternative theories include the pecking order /asymmetric information theory, trade-off theory and the agency theory. All these theories have been exposed to great deal of empirical testing in the context of developed countries, particularly the United States (US) (see Harris \& Raviv 1991 for a review) and United Kingdom (UK) and other developed countries. A few studies report on international comparisons of capital structure determinants (Raj an

\footnotetext{
*Author Abbas Ali, Lecturer in Business Administration, University of Gujrat, E-mail: abbas alis@yahoo.co.uk Phone \#+92-345-6941145, Pakistan.
} 
\& Zingales 1995; Wald 1999); and there are some studies that provide evidence on the capital structure determinants from the emerging markets of South-East Asia (Annuar \& Shamsher 1993; Ariff 1998; Pandey, Chotigeat \& Ranjit 2000; Pandey 2001). The recent focus of corporate finance empirical literature has been to identify some 'stylised' factors that determine capital structure.

\section{Introduction:}

The corporate financial policies involve capital structure, working capital requirements, dividend payments, optimal level of cash holding and cash flow management and asset management. As far as capital structure is concerned capital structure has been one of the most widely researched subjects in applied finance. Modigliani and Miller (1958) know as father of modern finance studied capital structure and they tried to answer the question how the mix of debt and equity in capital structure affects the firm value. Also the factors that can have impacts on firm's capital structure are very argumentative subject in the finance literature.

However, many researchers have continually proved that there is significant relationship between capital structure and firm value actually exists (e.g., Lubatkin and Chatterjee, 1994). The same Modigliani and Miller (1963) claimed that their model was not effective anymore if tax was taken into consideration. They proved that the existence of tax subsidies on interest payments cause the value of the firm to increase when equity is traded off for debt.

More recent literature, however, tends to be less interested on how the capital structure determines firm's value, and more on how changes in the capital structure of a company affects its governance structure which, consequentially, influences the ability of a firm to make strategic choices (Hitt, Hoskisson, and Harrison, 1991), and thus its overall performance (Jensen, 1986). Nowadays, the major concern for capital structure is how to resolve the conflict between owners and managers over the control of corporate resources (Jensen, 1989). Which is topic of great debate and known as agency theory or agency problems, that is why I include a variable in my model that is insider ownership to see how insider ownership effect the performance of corporations in Indian and Pakistan.

After more than fifty years of studies, researchers and economist have not reached a consensus on how and to what extent the mixture of securities (capital structure)' impacts on the value of firms and consequently it affects the shareholders wealth, performance and governance. However, the studies and empirical findings of the last decades have at least demonstrated that capital structure has more importance than in the simple Modigliani-Miller model. Probably we are far from reaching a consensus on the perfect combination between equity and debt, but the efforts of fifty years of studies have provided the evidence that capital structure does affect firm value, does affect executives' behaviour, and does affect future performance of the company.

After a brief summary of the theoretical literature on the different theories developed on the capital structure issue, this book will provide empirical evidence on the main determinants of capital structure and on whether capital structure does or does not affect firm's performance. The analysis is conducted on a sample of 40 companies listed on the Stock Exchange of Mauritius (SEM) whose data were averaged and divided into 6 main sectors. The determinants of leverage will be investigated by using panel data and the estimation methods will consist of descriptive statistics, correlations, and panel regressions supported by various diagnostic tests.

So far there have been tremendous studies conducted on effect of leverage and insider ownership on the capital structure policies of the corporations in Pakistan and India and these papers try to investigate the significant correlations between capital structure and possible firm specific characteristic having impact on it. However there is not a single published study which examines and compares the leverage and its impact on the profitability in the Pakistani and Indian stock markets. In this paper, researcher analyse leverage, insider ownership and shareholder's equity impact on the profitability of the listed companies in India and Pakistan stock exchange. The aim of this paper is to investigate whether there is a significant correlation between the firm performances (profitability) and firm specific characteristic like leverage, insider ownership and shareholders' equity as a percentage of total debt. The interesting thing about this paper is that this paper not only investigate the impact of leverage insider ownership and shareholders' equity participation on the profitability but it also compare the result within two Asian markets Pakistan and India.

\section{Literature Review:}

In this section a brief summary of the theoretical literature on the different theories developed on firm performance and capital structure is provided. However, this is simply a summary of the main arguments presented in the last fifty years and, by no means; it should be considered as a complete survey. In this chapter researcher will study the available literature and to discuss their significance and finding on the effect of leverage and insider ownership on the performance of corporations in Pakistan and India. Capital structure is the mixture of debt and equity capital. It has been one of the most argumentative subjects in corporate finance and there is still research going on to find how much company should mix the securities to maximize the value of shareholders. The finance literature on capital structure has developed after the paper of Modigliani and 
Miller (1958) was published. After 1958 we have seen lot of research work and criticism on the capital structure irrelevance argument of the Modigliani and Miller. Many theories have been developed in the literature for examining effect of leverage and insider ownership on the performance of corporations in Pakistan and India and they focus on which determinants are more likely to have a major role on the capital structure decisions. However, it is still debated what the effect of leverage and insider ownership on the performance of corporations in Pakistan and India are and how they impact capital structure decisions, even though there have been various studies conducted on the relevant subject. In this paper, the researcher intends to review fundamental capital structure theories briefly and give past empirical studies on effect of leverage and insider ownership on the performance of corporations in Pakistan and India.

Before going in detail I will present fundamental theories in applied finance that will help to better understand the effect of leverage and insider ownership on the performance of corporations in Pakistan and India.

\section{Modigliani and Miller theory of irrelevance}

According to Modigliani and Miller theory of irrelevance, "The value of the firm is determined by the left-hand side of the balance sheet that is by real assets and they remain unaffected whether the liability side of the firm's balance sheet is sliced into more or less debt, so in other word liability sides doesn't matters and it doesn't affect the shareholders wealth maximization. Therefore, to increase the value of the firm and consequently add value to the shareholders wealth, investment should be done in positive net present value projects" (Brealey, Myers and Allen, 2006).

\section{Financial Distress and Trade-off Theory}

Financial distress has an important position in capital structure theories. Berk and DeMarzo (2007, p. 509) define financial cost as "when a firm has trouble meeting its debt obligations we say the firm is in financial distress". When a firm increases its proportion of debt to equity for financing its operations and future investments, the probability of default on the debt will raise as well (Kraus and Litzenberger, 1973). The cost arising from financial distress plays crucial role on the firm "s future decisions such as, investment policy, cuts in research and development activities, advertisement and educational expenditures (Warner, 1977). All these decisions as an outcome of financial distress will affect firm"s value negatively and lead to decline in the firm" $\mathrm{s}$ value; therefore the wealth of shareholders will decrease as well. There are two types of costs arising from financial distress, direct and indirect cost. Direct costs are bankruptcy fee, administrative fee and legal costs as well (Warner, 1977). Indirect costs arise from firm's decision-makings due to financial distress. These are, as mentioned above, changes in investment policy such as, postponing future positive NPV investments or totally discarding investment opportunity, decrease in staff educational expenditures and reducing research and development and marketing activities (Arnold, 2008). The trade-off theory states that interest tax shield and cost of bankruptcy (financial distress) plays crucial role on firm's leveraged ratio. This theory suggest that the total value of a geared firm equals the value of the ungeared firm plus present value of the interest tax shield, minus the present value of financial cost (Berk and DeMarzo, 2007). Therefore the firm looks for optimum debt ratio, which offsets tax savings benefits opposing to the cost of possible bankruptcy and agency conflict (Gajurel, 2005).

According to the trade-off theory, companies that make high profits are more likely to have higher leverage and more taxable income to shield (Barclay and Smith, 2005). However, Rajan and Zingales (1995) study shows that this theory fails in some cases to illuminate why profitable firms have low debt ratio. Also Bevan and Danbolt (2002) suggest that the trade-off theory has some shortcomings and limitations. In addition to these empirical studies of Kester (1986) and Titman and Wessels (1988), which supports that, there is strong inverse correlation between profitability and debt ratios in capital structure. As a result, due to shortcomings and flaws of trade-off theory, the theory is not adequate when determining the ideal capital structure.

\section{Pecking Order Theory}

Myers and Majluf (1984) proposed the pecking order theory that firms would prefer retained earnings as a primary source of internal financing. If internal financing does not meet the requirements, then firms prefer external financing by issuing securities. According to Myers (1984), if the firm is need of using external finance, firm chooses first the safest security (debt market) to issue rather than convertible bonds. As a last choice, the firm recourses equity market and issue external equity.

The firm that has not enough available internal finance would either use equity or debt issue to finance future positive NPV investments. According to Myers and Majluf (1984), issuing external equity gives a bad signal to the market that supporting equity is overrated. Nevertheless issuing debt sends a signal supporting stock is underestimated. This conflict leads to an interaction between investment and financing decision ${ }^{\text {e }}$ (Gajurel, 2005, p. 19). 
The pecking order theory suggests that there is no exact target level of leverage and interest tax shield and financial distress are considered as less effective factors when determining capital structure decisions (Myers, 2001). Also he further advocates that trade-off theory does not differentiate finance equities as external and internal and states that there is a positive correlation between profitability and debt ratio. Nevertheless pecking order theory advocates a negatively correlated relationship and Myers and Majluf (1984) suggest less profitable firms are more like to borrow more debt to finance future positive NPV investments; therefore the firm will raise its profitability. In addition to this, the studies of Ozkan (2001), Kester (1986) and Titman and Wessels (1988) support inverse relationship between leverage and profitability. As a result, pecking order theory is much more accurate in order to explain reverse relationship of profitability and debt ratios rather than trade-off theory.

\section{Agency Cost:}

Jensen and Meckling (1976) defined agency costs as examining conflicts and relationships between the agent (managers) and principals (shareholders). The opposed interests of principals and agents and separation of management and ownership in a firm cause these conflicts. For instance, managers may be interested in taking negative NPV projects or making unnecessary acquisitions by paying too much to increase size and reputation of the firm instead of maximising the wealth of shareholder because managers get highly paid from the big companies. Summing up, managers try to operate the firm in their interest rather than taking into consideration of increasing the shareholders wealth and value of firm.

Harris and Raviv (1991) and Jensen (1986) describe two types of conflicts, the agency cost of equity and the agency cost of debt. The agency cost of equity, as mentioned above, is between shareholders and managers and small firms generally do not suffer from this cost since they are mostly operated by owners (Easterbrook, 1984). This cost emerges from management different interests, which are not corresponded to maximising stockholder wealth. The agency cost of debt is between equity holders and debt holders and this conflict arises from risk shifting which means transferring risk from debt holders to equity holders by making risky investments with debt (Jensen, 1986).

Jensen (1986) also states that a firm, which has high levels of excess cash, is more likely to experience agency cost. When excess cash is reducing and debt is increasing, it would limit the availability of money for future investments and spending. Hence managers tend to manage firm more attentively not to face financial distress and this decreases possibility of experiencing agency cost. According to Harris and Raviv (1991) study, leverage is used as a tool for providing motivation and discipline for management and minimising agency cost. In conclusion, Harris and Raviv (1991) further state that there is a positive relationship between leverage and free cash flow, company value and liquidity.

\section{Past Empirical Studies}

When the past empirical studies are analysed, there is still no generally accepted model on effect of leverage and insider ownership on the performance of corporations in Pakistan and India. Each researcher takes into consideration different determinants that impact the level of debt ratio.

\section{Empirical Evidences from United States}

The empirical literature presented for united States are Ferri and Jones (1979) and Titman and Wessels (1988). Ferri and Jones (1979) investigated the relationship between a firm's financial structure and its industrial class, size, variability of income and operating leverage. The study developed taxonomy of firms which was based on the data gathered for two five years' time period that is from 1969-1974 and 1

971-1976. It was found that industry class directly effects firm's leverage, size is negatively related to leverage, variation in income is insignificant to form the financial structure and operating leverage negatively influences leverage. Titman and Wessels (1988) applied factor analytic technique for estimating the effect of leverage and insider ownership on the performance of corporations in Pakistan and India. The variables of the study were analysed from 1974 to 1982 . They concluded that short term debt ratios to be negatively related to firm size and uniqueness. Moreover, they results were inconclusive regarding the effect of debt ratios arising from non-debt tax shields, volatility, collateral value of assets and future growth.

\section{Empirical Evidences from United Kingdom}

In order to include the empirical evidence for United Kingdom, three studies have been selected which includes Ozkan (2001), Bennett and Donnelly (1993) and Bevan and Danbolt (2004). Ozkan (2001) investigated the effect of leverage and insider ownership on the performance of corporations in Pakistan and India and the role of adjustment process using a partial adjustment model. Panel data was constructed for 390 non-financial firms for the period 1984-1996. the results of the study are as follows (1) profitability, liquidity and growth opportunities were found to be negatively related to leverage, (2) inverse relationship between non debt tax 
shields and borrowing ratio of firm (3) limited positive support was found between size and leverage. Bennett and Donnelly (1993) utilized regression analysis to capture the effect of leverage and insider ownership on the performance of corporations in Pakistan and India. Using a 12 year data for the years 1977-1988 they found that non-dent tax shields, size, asset structure and past profitability of firms are related to capital structure as suggested by the theory. However, they found a positive relationship between volatility and leverage.

Bevan and Danbolt (2004) analysed the effect of leverage and insider ownership on the performance of corporations in Pakistan and India of 1054 UK Companies from the period 1991-1997. Secondly, they also investigated the extent to which the influence of these determinants is affected by time-invariant and firm specific heterogeneity. The results under OLS method support the prior literature. However, the results of the fixed affects method showed that larger companies have higher levels of long and short term debt than smaller firms. Moreover, they found profitability to be negatively correlated with the level of gearing and the level of growth opportunities has little influence of the leverage ratio.

\section{Newly Added Stuff:}

The empirical study conducted by Smith (1990) on 58 Management Buyouts (MBO) of publicly traded companies completed during 1977-1986 provided the existence of the positive correlation between firm's performance and management ownership (Insider ownership). The operating returns of the firms examined by Smith increased significantly from the year before the buyout and it remained at a higher level also during the subsequent years. Moreover, the study of Smith (1990) also proved that the increase in operating income was not merely due to cuts to advertising expenses or research and development, but to reductions in operating costs and improvements of the working capital management. After the MBO firms were on average reducing the account receivable collection period and the holding period of inventories. Similar results are found in the studies of Kaplan (1989), and of Lichtenberg and Siegel (1990), which conclude that the increase in operating returns that follows MBOs is almost exclusively due to an increase in operating efficiency.

\section{Data and Methodology:}

The study uses data of 73 non-financial companies listed on the Karachi Stock Exchange Pakistan for the period from 2000 to 2010 inclusive both year and 83 non-financial companies listed on the Bombay stock exchange for the period from 2000 to 2010 inclusive both year. There were 16 banks in KSE 100 index and 4 other financial services and 10 banks in BSE 100 index and 7 other financial services. The companies with missing data and newly quoted companies were excluded from the study. This study also exclude financial and securities sector companies, as their financial characteristics and use of leverage are substantially different from other companies. In addition, the balance sheets of the firms in the financial sector (banks, insurance companies, and investments trust) have a significantly different structure from those of non-financial firms; therefore, financial firms were excluded from the sample. The secondary data for the study consist of selected variables from the financial statements of sampled firms. The estimation model uses panel data. Panel data econometric techniques were employed for the study. The Pooled Ordinary Least Squares (OLS) model, Fixed Effect Model and Random Effect Model were used in the analysis, which covered the data from 2000 to 2010. The estimation equation is as follow:

PROF $=\mathrm{f}($ LEV1, LEV2, Insider ownership, PL)

Where:

PROF $=$ Profitability (earnings before interest and tax)

LEV1 $=$ Total liabilities ratio

LEV2 $=$ Long-term liabilities ratio

LEV3 $=$ Short-term liabilities ratio

Insider Ownership = percentage of shares held by the insiders

$\mathrm{PL}=$ Participation of Equity

Profitability is defined as earnings before interest and tax divided by the total assets. Independent variables include long-term debt ratio, short-term debt ratio, insider ownership and participation of equity. Long term debt ratio refers to the total debt divided by total assets (LEV1), while short-term debt ratio is the ratio of shortterm debt divided by total assets (LEV2). Insider ownership refers to the percentage of the shares held by the insiders (Directors, Managers, employees etc) and the participation of equity (PL) is defined as the ratio of shareholders equity to the total debts.

Many of the empirical studies in the literature have relied only on the ordinary least square estimation model which may have resulted in partial and biased results. Therefore, this study not only used the pooled OLS model but took into consideration the results of the fixed estimation model and random effect model. Finally, the study also aimed to provide an up to date examination of the capital structure decisions. There are 3 
competing panel estimation models which include pooled ordinary least square (OLS), fixed effects model and the random effects model. Each of the models is subject to limitations and therefore, using one method alone will not be effective. Thus, the dataset of the study is tested by using all three models. One other reason for using the three models comes from the work of Bevan and Danbolt (2004). In their paper, they noted that the OLS estimation model has widely appeared in the literature but due to the limitations of the model that is the failure to control for time invariant firm specific heterogeneity, the results are likely to be biased. Thus, by applying the other two models, the results can now be compared with the OLS estimation model.

\section{Results and discussion:}

The choice between debt and equity is vital decision that corporate managers undertake at the corporate level. The capital structure decisions effects the firm's level of earnings and risk attached to it and its assets valuation. So this section reveals the analysis on the impact of leverage, insider ownership and shareholders' equity on the profitability of Pakistani and Indian listed companies. The results of the analysis of the regression estimated to evaluate the influence of the capital structure on the profitability are shown in following Tables.

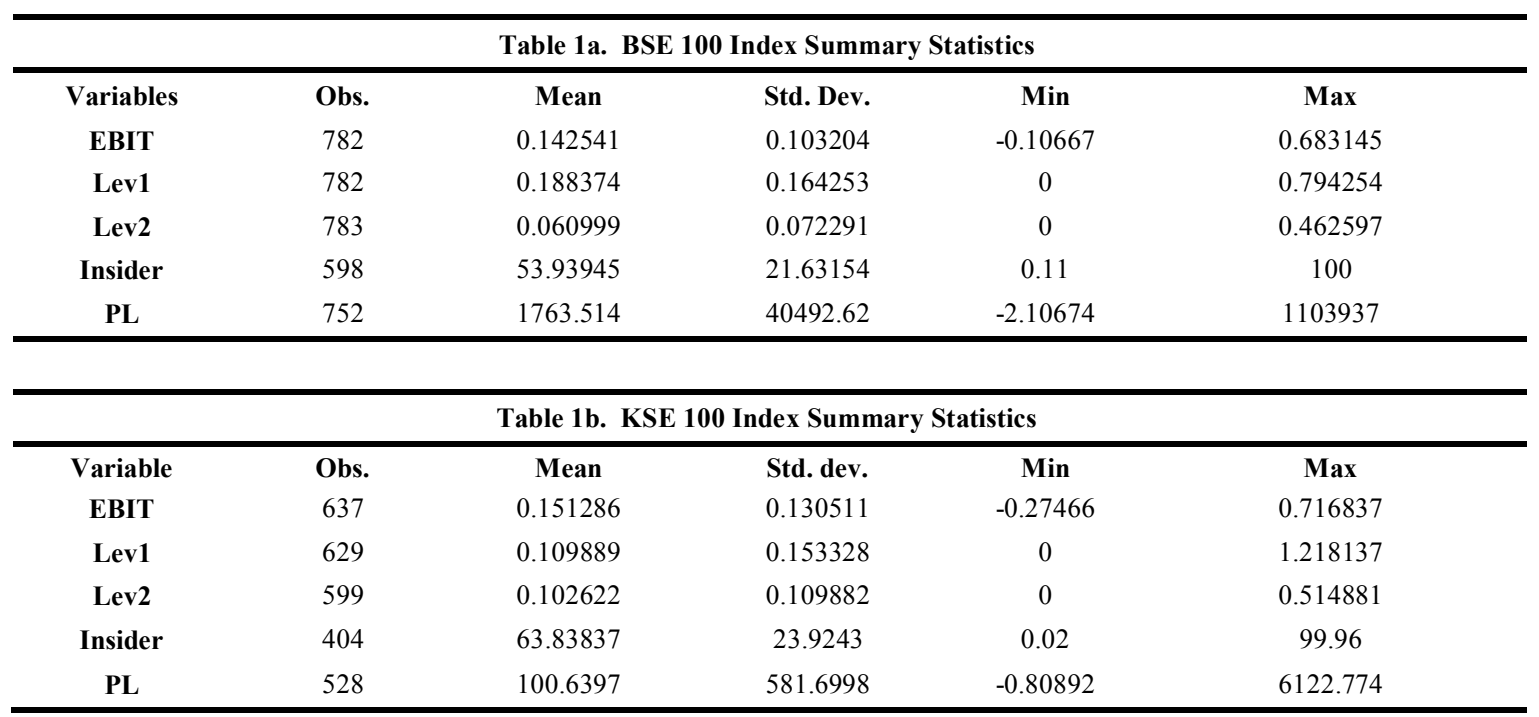

The data in Table 1 present the average indicators Summary statistics shows the mean, high, low value and standard deviation of the variables and provide a general overview of the characteristics of the data. The average return rate (PROF) measured by the earning after interest and tax divided by net assets gives positive values, that is, .1425414, 0.1512861 for the India and Pakistan listed corporations respectively. This indicates that the companies listed in Karachi stock exchange Pakistan shows better performance on average as compared to the Indian listed companies.

The long term (LEV1) on average amount to about $10.98 \%, 18.83 \%$ for Karachi and Bombay respectively that shows that corporations in the India are more leveraged as compared to the Pakistan. The short term financing shows different and opposite pictures for corporation in both countries with $10 \%, 6 \%$ for Karachi and Bombay listed corporations. That shows corporations in India use long term financing more than compared to Pakistani corporation that rely more on the short term financing for their total financing needs. The participation of equity in the financing of the companies measured by equity on total debts (PL) presents average of 0.8388 and standard deviation of 1.7047 . The results suggest a certain uniformity of that capital source, that is, an elevated number of companies falls back mainly upon equity as a financing form. The values are quite high, that is, justified by the low long-term debt level.

\begin{tabular}{cccccc}
\hline \multicolumn{5}{c}{ Table 2a. KSE 100 Index Correlation Matrix } & Insider \\
\hline EBIT & EBIT & Lev1 & Lev2 & PL & \\
Lev1 & 1 & & & & \\
Lev2 & $\mathbf{- 0 . 3 7 2 5}$ & 1 & & & 1 \\
Insider & -0.2268 & 0.1818 & 1 & \\
PL & 0.1935 & -0.149 & -0.1234 & 0.1156 & 1 \\
\hline
\end{tabular}




\begin{tabular}{cccccc}
\hline \multicolumn{7}{c}{ Table 2b. BSE 100 Index Correlation Matrix } & PL \\
\hline EBIT & EBIT & Lev 1 & Lev 2 & Insider & \\
Lev 1 & 1 & & & & \\
Lev 2 & $\mathbf{- 0 . 4 7 7 2}$ & 1 & & & \\
Insider & -0.3102 & 0.0523 & 1 & 1 \\
PL & 0.0525 & -0.132 & 0.0441 & -0.0101 & 1 \\
\hline
\end{tabular}

The correlation coefficients show that multi co linearity is not an issue of concern as shown in tables not a single variable both depend and independent have pair wise correlation of more than .50. As show in the above table EBIT profitability is negatively correlated in Karachi stock exchange listed companies to long term debt to total assets ratio and same is the case with the Bombay stock exchange listed companies and the strength of association is more in Bombay as compared to Karachi stock exchange listed companies which shows that firms in India use more leverage as compared to Pakistani firms. Likewise short term leverage is also negatively correlated to the profitability in both countries and strength of association in Indian firms is more as compared to Pakistani listed firms. Insider ownership and participation of equity both positively correlated to EBIT (profitability) in Pakistani and Indian firms.

Profitability is statistically significant only in case of short-term debt, indicative of the fact that more profitable firms resort to less usage of debt by relying more on internal funds. Similarly, non-debt tax shield is found to be solely statistically significant in case of long term liabilities. However, for the rest of the dependent variables, the growth, profitability and non-debt tax shield variables are all found not to statistically affect leverage, though, they all do exhibit signs consistent with the Pecking Order Theory. These findings clearly show that the use of specific leverage variables may bias results to the effect that decomposition is warranted to generate richer understanding. Nevertheless, impotency of the growth variable implies that higher growth does not signify use of more leverage as firms try to concentrate gains among themselves.

Regarding asset structure, a positive effect is found meaning that greater tangibility of assets initiates higher value for collaterals and hence eligibility for a higher amount of leverage consistent with findings of Rajan and Zingales (1995). However, the positive effect manifests in case long term liabilities, short term leases, long term loans and long term debt are employed as dependent variables because in case of total liabilities and short term liabilities a negative relationship is noted. Comparing leases and loans, it is found that the greater economic impact manifests for long term loans which implies that greater the value of fixed assets such as land and buildings, banks are then able to provide a higher amount of long term loans by having these assets encumbered in their favour.

\begin{tabular}{|c|c|c|c|}
\hline & \multicolumn{2}{|c|}{ BSE (Bombay) 100 index } & \multirow[b]{2}{*}{ Fixed } \\
\hline \multirow{4}{*}{ Lev 1} & Pooled & Random & \\
\hline & -0.29171 & -0.31489 & -0.34405 \\
\hline & $(-13.03)^{*}$ & $(-11.96)^{*}$ & $(-11.15)^{*}$ \\
\hline & -0.39219 & -0.34446 & -0.35068 \\
\hline \multirow[t]{2}{*}{ Lev 2} & $(-8.14)^{*}$ & $(-7.04)^{*}$ & $(-6.62)^{*}$ \\
\hline & $2.19 \mathrm{E}-05$ & 0.000122 & 0.000394 \\
\hline \multirow[t]{2}{*}{ Insider } & $(0.13)$ & $(0.50)$ & $(1.19)$ \\
\hline & $9.58 \mathrm{E}-08$ & $6.75 \mathrm{E}-08$ & $6.23 \mathrm{E}-08$ \\
\hline PL & $(1.24)$ & $(1.21)$ & $(1.11)$ \\
\hline Number of Obs. & 573 & 573 & 573 \\
\hline \multirow[t]{2}{*}{ Cross sections included } & 80 & 80 & 80 \\
\hline & & & $\begin{array}{c}4.11 \\
(0.2496)\end{array}$ \\
\hline $\mathbf{R 2}$ & 0.3112 & 0.3083 & 0.3018 \\
\hline \multirow[t]{2}{*}{ Adj. R2 } & 0.3063 & $\begin{array}{c}\text { Within } \\
0.2440 \\
\text { Between }\end{array}$ & Within 0.2452 \\
\hline & & 0.2895 & Between 0.2783 \\
\hline
\end{tabular}

The table present pooled effect, random effect and fixed effect respectively, predicting the effect of leverage and insider ownership on the profitability. The test statistics are in parentheses. ${ }^{*}, * *$ and $* * *$ denote significant at $1 \%, 5 \%$ and $10 \%$ levels respectively.

Tables 2 present the results of the pooled OLS, fixed effects and random effects estimations for short term debt to total assets (LEV1), long-term debts to total assets (LEV2), insider ownership and participation of equity (PL) in the Bombay Stock exchange. Moreover, the outcome of the Hausman's specification test in the study rejects the hypothesis regarding the presences of correlation between the individual unobservable effects and the explanatory variables and, therefore, the choice should be the random effects. The Hausman test indicates that 
the random model should be used. The table random effect results for the determinants of firm's performance (profitability). The value of overall R2 is .1576 These variables explain 15 per cent of the factors that determine the firm's profitability with $\mathrm{p}$ value of 0.0000 for $\mathrm{F}$ statistics represent that the model is fairly fitted well statistically and the multicollinearity has been tested to estimate best model of OLS, VIF (variance inflation factor) indicate no evidence of multicollinearity with mean VIF of 1.01. And Breusche-pagan test for heteroscedasticity gave chi2 977.02 and corresponding $\mathrm{p}$ value is 0.0000 which indicate constant variance assumption is not violated because we are rejecting the null (Ho) that there is a problem of heteroscedasticity. The LEV1 (Long term debt) and LEV 2 (short term debt) has a negative sign of -.2917, -.3314, -.3440 and $.3921,-.3444,-.3506$ respectively under the three estimation techniques shown in the above table. The results indicate that the return rate or performance of firms (profitability) is inversely proportional to the both short term and long term debts. In other words, the larger the amounts of debt, the lower are the profitability. These results are in conformity with the conclusions of Booth et al (2001), Fama and French (1998), Graham (2000) and miller (1977) Kester (1986), Friend \& Lang (1988) and Titman \& Wessels (1988) Rajan \& Zingales (1995) Michaelas, Chittenden \& Poutziouris (1999).

Furthermore the percentage of shares held by the insiders is positively correlated to the profitability in the Bombay stock exchange listed corporations in all estimation models (pooled OLS, random effect, fixed effect) but none of estimation model showing significance result regarding effect of insiders ownership on the profitability of firms.

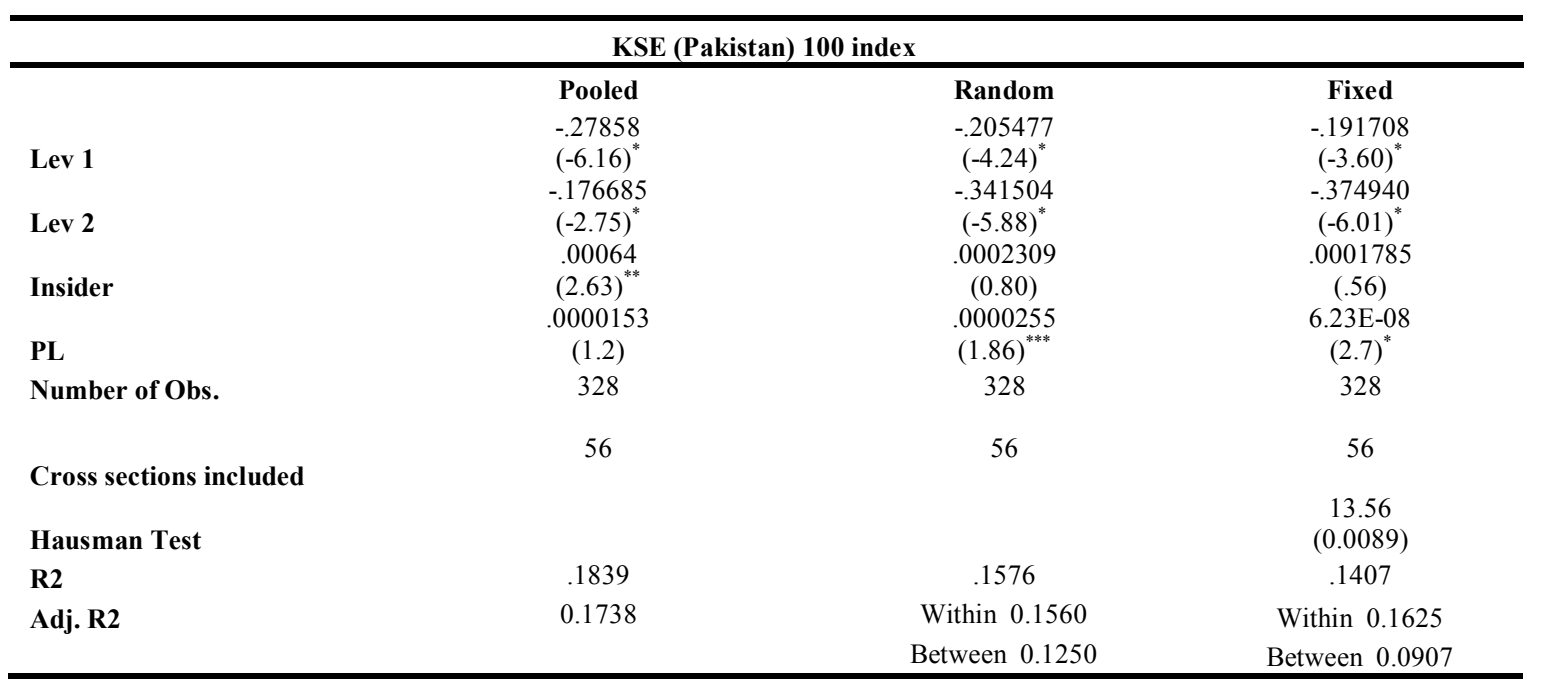

The table present pooled effect, random effect and fixed effect respectively, predicting the effect of leverage and insider ownership on the profitability. The test statistics are in parentheses. *, ** and $* * *$ denote significant at $1 \%, 5 \%$ and $10 \%$ levels respectively.

Tables 2 present the results of the pooled OLS, fixed effects and random effects estimations for short term debt to total assets (LEV1), long-term debts to total assets (LEV2), insider ownership and participation of equity (PL) in the Karachi stock exchange. Moreover, the outcome of the Hausman's specification test in the study rejects the hypothesis regarding the absence of correlation between the individual unobservable effects and the explanatory variables and, therefore, the choice should be the fixed effects. The Hausman test indicates that the fixed effect model should be used. The LEV1 (Long term debt) and LEV 2 (short term debt) has a negative sign of $-.2917,-.3314,-.3440$ and $-.3921,-.3444,-.3506$ respectively under the three estimation techniques shown in the above table.

The results indicate that the return rate or performance of firms (profitability) is inversely proportional to the both short term and long term debts. In other words, the larger the amounts of debt, the lower are the profitability. These results are in conformity with the conclusions of Booth et al (2001), Fama and French (1998), Graham (2000) and miller (1977). Insider ownership is positively correlated to the profitability of firms in Karachi stock exchange listed firms these result are similar with the Bombay stock exchange listed firms, these results shows that more the firms owned by the insiders more profitable the firms are. The participation of equity is also positively correlated to profitability of firms and it is significant at $1 \%$ and $10 \%$ level in pooled and fixed effect estimation models respectively. 


\section{Conclusion}

This purpose of this study is to find the influence of various firm level characteristics such as, leverage and insider ownership on the profitability of the Pakistan and India's corporations and then comparison of the finding between two countries. Employing the cross-sectional data methodology, i examine the leverage and profitability and insider ownership of 74 companies in Pakistan and 84 companies in India from KSE 100 index and BSE 100 index respectively for the time period of $2000-2010$ both years inclusive. Four variables multiple regression models are used to estimate the effect of firm level attributes on profitability or performance and capital structure is measured simultaneously by the ratios of total debt, long-term debt and short-term debt at both book value and market value of equity.

The results obtained from four different regression models show that profitability and liquidity are negatively and significantly related to leverage in both KSE and BSE listed corporations. Moreover I find that insider ownership is positively related to profitability and it is significant in the KSE and it is insignificant in BSE listed corporations. Moreover, the impact of capital structure on the profitability is significant, and there is negative relationship between profitability and short-term debt and long term debt measured as debt over total assets. The result suggests that firms in both countries depend on external financing. Furthermore participation of equity is positively related in to profitability of both KSE and BSE listed corporations which are showing significant impact with Karachi stock exchange listed companies that are significance at the $1 \%$ significance level and in Bombay stock exchange it is insignificant. Different conditional theories of capital structure are reviewed (the trade-off theory, pecking order theory, agency theory, and theory of free cash flow) these results are in conformity with the literature and finance theories.

In the Nigerian case, a high proportion $(60 \%)$ of the debt is represented in short-term debt. The participation of equity (PL) in the capital structure is positively correlated with profitability.

\section{Reference}

[1]. BREALEY, R. A., MYERS, S.C., and ALLEN, F., 2006. Principles of Corporate Finance. 8th edition, McGraw Hill.

[2]. Harris, M. and Raviv, A. (1991) „The Theory of Capital Structuree ${ }^{e e}$ The Journal of Finance, 46, 1, 297-355 [Online] Available at: http://www.jstor.org/stable/pdfplus/2328697.pdf (Accessed 2/6/2010)

[3]. Jensen, M. (1986) „Agency Costs of Free Cash Flow, Corporate Finance and Takeovers ${ }^{\text {ee }}$, The American Economic Review, 76(2), pp. 323-329 [Online]
[A Availableat:http://www.ecsocman.edu.ru/images/pubs/2007/10/25/0000314524/jensen_agency_costs_1986.pdf (Accessed $1 / 6 / 2010)$

[4]. Modigliani, F. and Miller, M. (1958) „The Cost of Capital, Corporation Finance and Theory of Investment ${ }^{e}$, The American Economic Review, 48(3), pp. 261-297 [Online] Available at: http://www.jstor.org/stable/1809766 (Accessed 1/6/2010)

[5]. Modigliani, F. and Miller, M. (1963) „Corporate income taxes and the cost of capital: a correction“, The American Economic Review, 53(3), pp. 433-443 [Online] Available at: http://www.jstor.org/stable/1809167 (Accessed 1/6/2010)

[6]. BEVAN, A.A., and DANBOLT, J., 2002. 'Capital Structure and Its Determinants in the UK - A Decompositional Analysis' Applied Financial Economics, 12(3): 159-170.

[7]. OZKAN, A., 2001. 'Determinants of capital structure and adjustment to long run target: Evidence from UK company panel data' The Journal of Business Finance and Accounting, 28(1): 175-197.

[8]. Jensen, M., 1986. Agency costs of free cash flow, corporate finance and takeovers. American Economic Review, 76, 323-329.

[9]. Berger, A.N. and Udell G.F., 1988. The economics of small business finance: the roles of private equity and debt markets in the financial growth cycle. Journal of Banking and Finance 22, 613-673.

[10]. Graham, J. R (1996), "Debt and the Marginal tax rate". Journal of Financial Economies, 41, p. 41- 74

[11]. Graham, J.R. (2000), "How Big are the Tax Benefits of Debt?” Journal of Finance 55 (No. 5, October), p. 1901 -1941.

[12]. Miller, M.H. (1977), "Debt and Taxes", Journal of Finance, Vol. 32.

[13]. Rajan, R.G. \& Zingales, L. 1995, 'What do we know about capital structure? Some evidence from international data', Journal of Finance, 50(5): 1421-60.

[14]. Michaelas, N., Chittenden, F. \& Poutziouris, P. 1999, 'Financial policy and capital structure choice in UK SMEs: empirical evidence from company panel data', Small Business Economics, 12: 113-3

[15]. Lubatkin, M. and Chatterjee, S. (1994). Extending modern portfolio theory into the domain of corporate diversification: Does it apply?. Academy of Management Journal, 37, pp. 109-136.

[16]. Hitt, M., Hoskisson, R. and Harrison, J. (1991). Strategic competitiveness in the 1990s: Challenges and opportunities for U.S executives. Academy of Management Executive, 5(2), pp. 7-22.

[17]. M. and Meckling, W. (1976). Theory of the Firm: Managerial Behaviour, Agency Costs, and Ownership Structure. Journal of Financial Economics, October, pp.305-360.

[18]. Jensen, M. (1986). Agency cost of free cash flow corporate finance and takeovers. American Economic Review Papers and Proceedings, 76, pp. 323-329.

[19]. Jensen, M. (1989). Eclipse of public corporation. Harvard Business Review, 67(5), pp. 61-74.

[20]. Harris, M. \& Raviv, A. 1991, 'The theory of capital structure', Journal of Finance, 46(1): 297-355.

[21]. Pandey, I.M. 2001, Capital structure and the firm characteristics: evidence from an emerging market, working paper 2001-10-04, Indian Institute of Management, Ahmedabad, India.

[22]. Ariff, M. 1998, Stock Pricing in Malaysia-Corporate Financial and Investment Management, UPM Press, Selangor, Malaysia.

[23]. Smith, A. (1990). Corporate ownership structure and performance. The case of Management Buyouts. Journal of Financial Economics, 27, pp.143-164.

[24]. Kaplan, S. (1989). The effects of management buyouts on operating performance and value. Journal of Financial Economics, 24, pp. 217- 254 .

[25]. Lichtenberg, F. and Siegel, D. (1990). The effects of leveraged buyouts on productivity and related aspects of firm behaviour. Journal of Financial Economics, 27. 


\section{Appendix}

\begin{tabular}{|c|c|c|c|c|c|c|}
\hline \multicolumn{7}{|c|}{ KSE 100 Index Pooled regression Results } \\
\hline & $\overline{\text { Ss }}$ & Df & $\mathrm{Ms}$ & & $\overline{\text { Obs. }}$ & 328 \\
\hline Source & 1.0173318 & 4 & 0.254332 & & $\mathrm{~F}(4,323)$ & 18.20 \\
\hline Model & 4.5133585 & 323 & 0.013973 & & $\mathrm{P}$ value & 0.00000 \\
\hline \multirow[t]{2}{*}{ Residual } & 5.5306902 & 327 & 0.016913 & & $\mathrm{R}^{2}$ & 0.1839 \\
\hline & & & & & Adj $R^{2}$ & 0.1738 \\
\hline EBIT & Coef & Std. err. & $\mathrm{T}$ & $\mathrm{p}>/ \mathrm{t} /$ & \multicolumn{2}{|c|}{$95 \%$ conf. interval } \\
\hline lev1 & -0.27858 & 0.045259 & -6.16 & 0.000 & -0.36762 & -0.189546 \\
\hline lev2 & -0.17669 & 0.064161 & -2.75 & 0.006 & -0.30291 & -0.05046 \\
\hline $\mathrm{Pl}$ & $1.53 \mathrm{E}-05$ & $1.28 \mathrm{E}-05$ & 1.2 & 0.232 & $-9.87 \mathrm{E}-06$ & 0.0000405 \\
\hline Insider & 0.000648 & 0.000274 & 2.36 & 0.019 & .0001086 & .0011876 \\
\hline Cons & 0.166512 & 0.021453 & 7.76 & 0.000 & .1243075 & .2087163 \\
\hline \multicolumn{7}{|c|}{ KSE 100 Index VIF } \\
\hline \multicolumn{2}{|r|}{ Variable } & \multicolumn{3}{|c|}{ VIF } & \multicolumn{2}{|c|}{$1 / \mathrm{VIF}$} \\
\hline \multicolumn{2}{|r|}{ lev2 } & \multicolumn{3}{|c|}{1.07} & \multicolumn{2}{|c|}{0.937559} \\
\hline \multicolumn{2}{|r|}{ lev1 } & \multicolumn{3}{|c|}{1.06} & \multicolumn{2}{|c|}{0.939156} \\
\hline \multicolumn{2}{|r|}{ Pl } & \multicolumn{3}{|c|}{1.05} & \multicolumn{2}{|c|}{0.948722} \\
\hline \multicolumn{2}{|r|}{ Insider } & \multicolumn{3}{|c|}{1.04} & \multicolumn{2}{|c|}{0.961719} \\
\hline \multicolumn{2}{|r|}{ mean vif } & \multicolumn{3}{|c|}{1.06} & & \\
\hline
\end{tabular}

\begin{tabular}{|c|c|c|c|c|c|c|}
\hline \multicolumn{7}{|c|}{ KSE 100 Index Random Effect } \\
\hline $\mathrm{R}^{2}$ Within & 0.1560 & & & Obs. & \multicolumn{2}{|c|}{328} \\
\hline $\mathrm{R}^{2}$ Between & 0.1250 & & & Group & \multicolumn{2}{|c|}{56} \\
\hline \multirow[t]{2}{*}{$\mathrm{R}^{2}$ Overall } & \multirow[t]{2}{*}{0.1576} & & & Chi 2 & \multicolumn{2}{|c|}{55.37} \\
\hline & & & & P Chi 2 & \multicolumn{2}{|c|}{0.0000} \\
\hline EBIT & Coef & Std. err. & $\mathrm{Z}$ & $\mathrm{p}>/ \mathrm{z} /$ & \multicolumn{2}{|c|}{$95 \%$ conf. interval } \\
\hline lev1 & -0.205477 & 0.0484636 & -4.24 & 0.000 & -0.30046 & -0.11049 \\
\hline lev2 & -0.341504 & 0.0580945 & -5.88 & 0.000 & -0.45537 & -0.227641 \\
\hline $\mathrm{Pl}$ & $2.55 \mathrm{E}-05$ & $1.37 \mathrm{E}-05$ & 1.86 & 0.063 & $-1.38 \mathrm{E}-06$ & 0.0000524 \\
\hline Insider & 0.0002309 & 0.0002876 & 0.8 & 0.422 & -0.00033 & 0.0007945 \\
\hline Cons & 0.1998779 & 0.0253597 & 7.88 & 0.000 & 0.150174 & 0.2495819 \\
\hline \multicolumn{7}{|c|}{ KSE 100 Index Fixed Effect } \\
\hline R2 Within & 0.1625 & & & Obs. & \multicolumn{2}{|c|}{328} \\
\hline R2 Between & 0.0907 & & & Group & \multicolumn{2}{|c|}{56} \\
\hline \multirow[t]{2}{*}{ R2 Overall } & 0.1407 & & & Chi 2 & \multicolumn{2}{|c|}{13.00} \\
\hline & & & & P Chi 2 & \multicolumn{2}{|c|}{0.0000} \\
\hline EBIT & Coef & Std. err. & $\mathrm{T}$ & $\mathrm{p}>/ \mathrm{t} /$ & \multicolumn{2}{|c|}{$95 \%$ conf. interval } \\
\hline lev1 & -0.191708 & 0.0532369 & -3.6 & 0.0000 & -0.29652 & -0.086892 \\
\hline lev2 & -0.374941 & 0.0623997 & -6.01 & 0.0000 & -0.4978 & -0.252085 \\
\hline $\mathrm{Pl}$ & 5.19E-05 & $1.92 \mathrm{E}-05$ & 2.7 & 0.007 & $1.40 \mathrm{E}-05$ & 0.0000897 \\
\hline Insider & 0.0001785 & 0.0003183 & 0.56 & 0.575 & -0.00045 & 0.0008052 \\
\hline \multirow[t]{3}{*}{ Cons } & 0.2031576 & 0.0236888 & 8.58 & 0.0000 & 0.156518 & 0.2497974 \\
\hline & \multicolumn{4}{|c|}{ KSE 100 Index Hausman Test } & & \\
\hline & Fixed & Random & & Difference & S.E. & \\
\hline lev1 & -0.191708 & -0.205477 & & 0.0137693 & 0.0220 & \\
\hline lev2 & -0.374941 & -0.341504 & & -0.0334366 & 0.0227 & \\
\hline PL & 0.0000519 & 0.0000255 & & 0.0000263 & 0.0000 & \\
\hline Insider & 0.0001785 & 0.0002309 & & -0.0000524 & 0.0001 & \\
\hline & Chi 2 (4) & 13.56 & & Prob $>$ Chi2 & 0.0008 & \\
\hline
\end{tabular}




\begin{tabular}{|c|c|c|c|c|c|c|}
\hline \multicolumn{7}{|c|}{ BSE 100 Index Pooled Regression } \\
\hline Source & SS & $\overline{\mathrm{Df}}$ & $\overline{\mathrm{MS}}$ & & Obs. & 573 \\
\hline Model & 1.876319 & 4 & 0.46908 & & $\mathrm{~F}(4,568)$ & 64.15 \\
\hline Residual & 4.153123 & 568 & 0.007312 & & P Value & 0.0000 \\
\hline \multirow[t]{2}{*}{ Total } & 6.029442 & 572 & 0.010541 & & $\mathrm{R}^{2}$ & 0.3112 \\
\hline & & & & & $\operatorname{Adj} R^{2}$ & 0.3063 \\
\hline EBIT & Coef. & Std. Err. & $\mathrm{T}$ & $\mathrm{P}>\mathrm{t}$ & \multicolumn{2}{|c|}{ [95\% Confidence Interval] } \\
\hline Lev1 & -0.29171 & 0.02239 & -13.03 & 0.000 & -0.33568 & -0.24773 \\
\hline Lev2 & -0.39219 & 0.04817 & -8.14 & 0.000 & -0.48681 & -0.29758 \\
\hline Insider & 2.19E-05 & 0.000172 & 0.13 & 0.899 & -0.00032 & 0.00036 \\
\hline${ }_{\mathrm{Pl}}^{\mathrm{T} \ldots \mathrm{T}}$ & $9.58 \mathrm{E}-08$ & 7.73E-08 & 1.24 & 0.216 & $-5.60 \mathrm{E}-08$ & $2.48 \mathrm{E}-07$ \\
\hline Cons & 0.224409 & 0.011465 & 19.57 & 0.000 & 0.20189 & 0.246928 \\
\hline \multicolumn{7}{|c|}{ BSE 100 Index VIF } \\
\hline & Variable & & \multicolumn{2}{|c|}{ VIF } & \multicolumn{2}{|c|}{$1 / \mathrm{VIF}$} \\
\hline & Lev1 & & \multicolumn{2}{|c|}{1.02} & \multicolumn{2}{|c|}{0.975838} \\
\hline & Lev2 & & \multicolumn{2}{|c|}{1.01} & \multicolumn{2}{|c|}{0.993137} \\
\hline & $\mathrm{Pl}$ & & \multicolumn{2}{|c|}{1.01} & \multicolumn{2}{|c|}{0.994959} \\
\hline & Insider & & \multicolumn{2}{|c|}{1.02} & \multicolumn{2}{|c|}{0.979500} \\
\hline & Mean VIF & & \multicolumn{2}{|c|}{1.01} & & \\
\hline
\end{tabular}

\begin{tabular}{|c|c|c|c|c|c|c|}
\hline \multicolumn{7}{|c|}{ BSE 100 Index Random Effect } \\
\hline $\mathrm{R}^{2}$ Within & \multicolumn{2}{|c|}{0.2440} & & & Obs. & 573 \\
\hline $\mathrm{R}^{2}$ Between & \multicolumn{2}{|c|}{0.2895} & & & Group & 80 \\
\hline \multirow[t]{2}{*}{$\mathrm{R}^{2}$ Overall } & \multicolumn{2}{|c|}{0.3083} & & & Chi 2 & 188.45 \\
\hline & & & & & P Chi 2 & 0.0000 \\
\hline Ebit & Coef. & Std. Err. & Z & $\mathrm{P}>\mathrm{Z}$ & $\begin{array}{c}{[95 \% \text { Conf }} \\
\text { Interval] }\end{array}$ & \\
\hline Lev1 & -0.31489 & 0.026329 & -11.96 & 0.000 & -0.36649 & -0.26328 \\
\hline Lev2 & -0.34446 & 0.048915 & -7.04 & 0.000 & -0.44033 & -0.24858 \\
\hline Insider & 0.000122 & 0.000246 & 0.5 & 0.62 & -0.00036 & 0.000604 \\
\hline $\mathrm{Pl}$ & $6.75 \mathrm{E}-08$ & $5.58 \mathrm{E}-08$ & 1.21 & 0.226 & $-4.18 \mathrm{E}-08$ & $1.77 \mathrm{E}-07$ \\
\hline Cons & 0.21729 & 0.016527 & 13.51 & 0.000 & 0.184897 & 0.249683 \\
\hline
\end{tabular}

\begin{tabular}{|c|c|c|c|c|c|c|}
\hline \multicolumn{7}{|c|}{ BSE 100 Index Fixed Effect } \\
\hline $\mathrm{R}^{2}$ Within & 0.2452 & & & & Obs. & 573 \\
\hline $\begin{array}{l}\mathrm{R}^{2} \text { Between } \\
\mathrm{R}^{2} \text { Overall }\end{array}$ & $\begin{array}{l}0.2783 \\
0.3018\end{array}$ & & & & $\begin{array}{c}\text { Group } \\
\text { Chi } 2 \\
\text { P Chi } 2\end{array}$ & $\begin{array}{c}80 \\
39.72 \\
0.0000\end{array}$ \\
\hline Ebit & Coef. & Std. Err & Z & $\mathrm{P}>|\mathrm{t}|$ & \multicolumn{2}{|c|}{ [95\% Conf. Interval] } \\
\hline Lev1 & -0.34405 & 0.030848 & -11.15 & 0.0000 & -0.40462 & -0.28344 \\
\hline Lev2 & -0.35068 & 0.053 & -6.62 & 0.0000 & -0.45481 & -0.24654 \\
\hline Insider & 0.000394 & 0.00033 & 1.19 & 0.234 & -0.00026 & 0.001043 \\
\hline $\mathrm{Pl}$ & $6.23 \mathrm{E}-08$ & $5.60 \mathrm{E}-08$ & 1.11 & 0.266 & $-4.77 \mathrm{E}+08$ & $1.72 \mathrm{E}-07$ \\
\hline Cons & 0.211536 & 0.018707 & 11.31 & 0.0000 & 0.174779 & 0.248293 \\
\hline \multicolumn{7}{|c|}{ BSE 100 Index Hausman Test } \\
\hline & Fixed effect & $\begin{array}{c}\text { Random } \\
\text { effect }\end{array}$ & \multicolumn{2}{|c|}{ Difference } & \multicolumn{2}{|c|}{ S.E } \\
\hline Lev1 & -0.34405 & -0.31489 & \multicolumn{2}{|c|}{-0.02916} & \multicolumn{2}{|c|}{.0160746} \\
\hline Lev 2 & -0.35068 & -0.34446 & \multicolumn{2}{|c|}{-0.006222} & \multicolumn{2}{|c|}{.0204029} \\
\hline Insider & 0.000394 & 0.000122 & \multicolumn{2}{|c|}{0.002715} & \multicolumn{2}{|c|}{.0002206} \\
\hline $\mathrm{Pl}$ & $6.23 \mathrm{E}-08$ & $6.75 \mathrm{e}-\mathrm{o} 8$ & \multicolumn{2}{|c|}{$-5.20 \mathrm{E}-09$} & \multicolumn{2}{|c|}{ 4.88E-09 } \\
\hline & Chi 2 (4) & 4.11 & \multicolumn{2}{|c|}{ Prob $>$ Chi2 } & \multicolumn{2}{|c|}{0.2496} \\
\hline
\end{tabular}

